\title{
A Distant Jaguar
}

\section{The Civil Society Project in Chimalapas}

\author{
Molly Doane \\ University of Oklahoma
}

\begin{abstract}
A bstract - Civil society has become an important unit of analysis in the context of the globalization of politics and political discourse and the decentralization of nation-states. At a discursive level, it is a concept which elides notions of democracy with privatization. This elision makes for confusion at the analytical level, since civil society rhetoric is deployed by state agencies and those social actors, like NGOs, that see themselves as autonomous from the state. Within Mexico, social actors represent civil society as separate and opposed to the 'state'. But a history of cooperation and cooptation between organs of the state and the social sector blurs these lines, practically if not ideologically. These issues are explored through a case study of an $\mathrm{NGO} /$ community environmental mobilization in Oaxaca, Mexico.

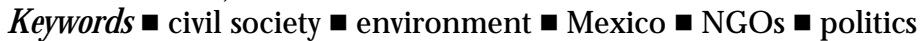

It's sort of like 'sleeping with the enemy'. We're asking them [ the campesinos] to turn around and say 'we realize the government hasn't supported our rights in the past, but now we think they're going to support our rights'. ( Jim Rieger,

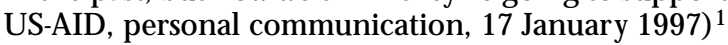

\section{Introduction}

In 1991, Maderas del Pueblo del Sureste, A.C. (hereafter, MPS), a Mexican NGO, won a five year grant to help plan and implement a locally managed 'Campesino Ecological Reserve' in the Chimalapas Forest of $O$ axaca, Mexico. This program was funded by the World Wildlife Fund (WWF) through the Biodiversity Support Program (BSP) of US-AID (MPS, 1996), a development agency housed in the U nited States Department of State. MPS fit the WWF criteria for sponsorship exactly: operating with a joint campesino (rural worker) and professional staff, they were well positioned to carry out technical projects with full community support and acceptance. Linked to broad networks of environmentalists, ${ }^{2}$ MPS had powerful connections to environment-minded government officials in Mexico (Umlas, 1998). This was a crucial fact, since the BSP:

CRTITUEFo o ANTHROPOLOCY 
... work[s] with developing country governments and non-governmental organizations to design and implement innovative conservation and development projects to strengthen local capacity for conservation efforts. (Daven port, 1995: 9, emphasis added)

By the time I began my fieldwork in October of 1996, MPS had been expelled from one of the two major municipios (counties), which together control the 600,000 hectares of ter ritory that is Chimalapas. Relations with the WWF were strained; negotiations with governmental environmental agencies had deteriorated; 3 and communication with the two agencies in charge of agrarian complaints ${ }^{4}$ had broken down completely.

It was in this context that funders expressed frustration at what they regarded to be political intransigence and a certain ideological purity on the part of Maderas del Pueblo. While acknowledging that many of the problems in Chimalapas, including land tenure disputes, border ambiguities, deforestation, over-grazing and the like could be attributed to government policies, spokespeople from the WWF and US-AID emphasized the necessity of cooperation and negotiation, implying that to retain their funding, MPS and their campesino constituency would have to 'sleep with the enemy'. Clearly AID officials themselves did not regard the M exican government as an 'enemy', but they did regard the presence of NGO s in developing countries as an opportunity to expand rural democratization, and explained that the precursorsfor conservation are 'democracy, participation and economic development' (Frank Zadroga, US-AID, 17 January 1996).

Maderas del Pueblo and groups like it (see Chalmers et al., 1995) are the poster-children of what is referred to as civil society - that pocket of democratic possibilities which has opened with the waning of the centralized state. In this article, I will use the case of MPS and Chimalapas to examine how civil society has become an important discourse on the social changes taking place in the Mexico of the Millennium.

As a discourse, civil society presentsa paradox, describing an Enlightenment vision of universalism from whence our modern conception of citizenship is derived, while championing the local, itself a peculiarly Romantic project. Sometimes used synonymously with the 'NGO Sector', civil society is often understood as 'grassroots', growing from particular places, while its local projects are defended by outsiders ( professionals and career activists), using international funds. Within the concept as discourse there is an antinomy between what we define as universal rights and the kind of citizenship that implies a respect for local, indigenous identities and determinations. Although these latter identities are often cast as 'traditional' or 'ancient', they are highly contested at the local level and must be regarded as historical and political constructs (Dirks et al., 1994).

In western political theory, civil society is a term which has been used at once to define the state and the working of its power, and to describe a force which is always working against or outside the state (Cohen and Arato, 1994). In officialist discourse it is used to denote a process wherein 
neoliberalism opens spaces for democracy, leading to the rise of civil society. Among activists, particularly those on the left, the term has a critical edge. Opposed to the decentralization and downsizing processes that characterize Mexico of the 1990s, these activists regard civil society as a champion for the people against the state (see Dagnino, 1998). Civil society is the reification of the people against the reification of power. Finally, insofar as civil society is equated with the NGO sector, the concept elides notions of public and private, transforming democracy into a private good.

In Chimalapas, civil society discourse links goals of community autonomy to globalizing discourses of politics and the environment. It creates a space in the community for urban activists and their representations. At the same time, the fact that NGOs are not elected and have little or no public accountability undermines their claims to community representation. This fact puts the local government, which, by whatever means, is elected, in a strong position to appropriate and redeploy civil society discourse to build power and constituency in the communities. After briefly overviewing the general Mexican context, I will go on to explore these issues by analyzing the events and discourse at and around a 'Forum of Community and Civil Society on the Chimalapas Forest' held in O ctober of 1996.

\section{Context: civil society in Mexico}

The growth of civil society, in this context understood as a sector made up of organizations and mobilizations which function outside of government control, is considered by policy analysts to be a sine qua non for democratic transition as well as the expansion of free markets (Fox, 1994, 1995). In the 1990s, development money had been directed less at large scale infrastructural projects (such as dams) and more toward funding 'grassroots development', often through NGOs.

In Mexico, the emergence of civil society is often traced back to 1968 , when students organized against the central control of the PRI (ruling party) . After 1968, elements of campesino, worker and student organizations, formerly incorporated in official PRI organs, began to constitute themselves as politically autonomous units ( $\mathrm{H}$ arvey, 1998). After the debt crisis of 1982, the subsequent contraction of the 1970s oil-boom economy, and the resulting International Monetary Fund restructuring, M exico could no longer maintain a corporate state with the social programs that had formerly worked to absorb and demobilize social protest. At the same time, new social movements and the NGO sector expanded in response to this void (H arvey, 1998; Nash, 1998). But as H ellman (1994) has also argued, popular groups themselves are sometimes clientalistic, working to extract favors from the ruling party for particular constituencies rather than to promote democratization per se. Their existence does not therefore constitute a threat to the state. 
On the other hand, the history of clientalism and cooptation in M exico makes new social movements distrustful of the state and political parties, including those of the left. Autonomy from party politics is regarded by social movements as a necessary precursor for democratic social change. These groups argue that because traditional left parties want to tap into the strength of social movements in order to bolster their own entrenched positions, they actually threaten the power of the masses on the left (Hellman, 1992).

The revolutionary model that legitimizes Mexican nationalism in the eyes of the left harks back to radical revolutionaries like Zapata who called for land redistribution and social programs for the rural population. The revolution of Zapata sought to redress the development course taken during the Liberal period (1854-1911). The liberal reform laws of President Benito Juarez had disempowered the Church, but also had the effect of breaking up corporate peasant holdings and privatizing communal lands.

The more moderate elements of the revolution whose policies eventually won out were more concerned with stemming the worst abuses of the subsequent years when President Por firio Díaz installed himself as a dictator. $\mathrm{He}$ formed close alliances with the United States and permitted development of Mexican railroads and oil resources by foreign business interests (Hamnett, 1999). The Constitution of 1917 nationalized resources and limited foreign investment in the country, but land redistribution remained more a nationalist discourse than a reality. Between 1934 and 1940, President Cárdenas set the course of a cooptive and centrist state. His reform program redistributed land to the peasantry. By making this new rural constituency automatic members of the state sponsored peasant union (CNC), he coopted their claims within the state. At the same time, he routed influences within the power structure that were interested in moving toward a Soviet model of state socialism ( $\mathrm{H}$ amnett, 1999). During the period of rapid development, urbanization and industrial expansion that followed (1940-1970), the redistributive rhetoric of the revolution declined.

The 1992 reforms to Article 27 of the Constitution effectively ended agrarian reform in M exico. These reforms made way for the kinds of free market policies necessary for the implementation of NAFTA in 1994. In official discourse, NAFTA legitimizes the course of economic development that has in fact been pursued by the state. For the left, NAFTA harks back to the worst abuses of the Liberal era and symbolizes the official end of the revolution.

Needless to say, poverty and landlessness are still compelling problems to social activists in M exico. As a result, some left activists have taken refuge in NGOs - where they work to reserve spaces within, but safe from, political parties and the state by using international funds. In this inverted space, professional NGO workers attempt to create small utopias. Among professional and non-professional activists alike the 
establishment of local autonomy has replaced revolution as a long-term organizing goal. ${ }^{5}$

While the mobilization in Chimalapas differs significantly from that of the Zapatistas (it is not armed and is influenced and shaped by NGO monies), both are framed within civil society discourse. The Zapatista uprising, which began on 1 January 1994 (marking the passage of NAFTA) in nearby Chiapas, is notable for being the first post-cold war, post-communist guer rilla movement in Latin America. It is also remarkable for its commitment to democracy. Among the media, the Zapatistas became famous for putting a global, post-modern face on revolution, uniting an international network of activists through the internet and journalist-friendly outdoor conferences in the jungle. In Chimalapas, the movement consciously refers to the nearby Zapatistas and its main concerns are identical: Iand, autonomy, and human rights ( see Collier and Stephens, 1997 on the Zapatistas).

\section{The Foro - invitations and denunciations}

In O ctober of 1996, the Committee for the Defense of Chimalapas (CNDC) held its first 'Forum of Community and Civil Society on the Chimalapas Forest' (the Foro). The event was funded by Synergos, a New York based group which supports grassroots development. MPS is the foot soldier and spokes-organ for the more nationally integrated CNDC, which includes among its members Guillermo Briseño, teen heartthrob from Mexico's popular rock group $M$ ana, and the even more famous singer, Emmanuel, as well as many environmental groups and scholars of note. The two day event brought local activists, environmentalists and urbanites alike from all over M exico and even abroad, where they met in the Chimalapas Forest of Southern Oaxaca, one of the remotest corners of Mexico. The invitation reads in part:

The agrarian authorities of the community of San Miguel Chimalapa, in coordination with Civil Society, invite independent, social and political organizations and indigenous communities to their first NATIONAL FORUM, to present a great ecological and social problem and its possible solutions...

The invitation echoes in its sweeping inclusiveness as well as in its remote forest locale the massive outdoor conferences organized by the Zapatistas in the nearby Lacandon Jungle, in which activists, scholars and journalists were invited to come together to both witness and solve the problems of Chiapas. Absent from the list of invitees are national political leaders, representatives of their political parties, or government officials. Invited are independent political and social organizations and indigenous communities. Thus, including both presences and absences, one would reasonably be able to suppose that the actors might roughly be divided into government, civil society and community. Who 'is' government, civil 
society, community? What is the 'great ecological and social problem' mentioned in the invitation and what are their respective roles in it?

Chimalapas is a forest region in Southern $\mathrm{O}$ axaca located between the Gulf of Mexico and the Pacific O cean, on the Isthmus of Tehauantepec. It is bordered by the state of Chiapas to the South and Veracruz to the East. The Isthmus is well-known for its vibrant Zapotec culture, and for Juchitán, which is the regional trade center. In contrast, the hills of Chimalapas rise abruptly from these hot tropical lowlands. Once a part of a larger forest which stretched to Veracruz in the North, Chimalapas is now a forest island, protected from development by its land tenure status. Uxpanapa (Veracruz) was deforested between the 1950s and the 1970s, when the Mexican government established new communities of poor peasants in the tropics. Whether attempting to place displaced citizens (refugees of dam projects or general poverty), to inscribe the nationalist desire for modernization into the landscape, or to create a tropical breadbasket and a rural middle class, the forest was converted to fruit, cattle and dust.

Chimalapas is home to two large, powerful municipalities, Santa María Chimalapa and San Miguel Chimalapa, which have political jurisdiction over the vast, wooded domain, and over 40 tiny, scattered communities who have either received permission to live there or moved in as squatters. Until recently, these two towns were the only settlementsin the region. The municipalities are inhabited by Zoque (the original ethnic group in the area) and Zapotec immigrants, who live by trading in precious woods and carpentry. Until the 1970s, when a graded dirt road was built, the residents of Santa María were isolated and considered backward and savage by their Isthmus neighbors. According to several informants, marijuana was the staple crop and Santa María was a violent place, a wild west where brothers killed brothers. As a result of this, the community banned marijuana. ${ }^{6}$ Timber companies moved into the area and the community transitioned into intensive logging and carpentry. M eanwhile, Santa M aría began to give immigrants permission to settle the forested peripheries of the area. This was to protect their distant borders from invading cattle ranchers and loggers.

Now there is a twofold problem: on the one hand, for residents of the area it is clear that forest resources are finite and will not support the local economy forever. On the other hand, environmentalists are concerned about stopping deforestation before the significant floral and faunal resources of the area are decimated. As a result, two major development projects have come into the area; one promoted by environmental NGOs and the other promoted by the government (through a variety of local agencies). The environmentalist project is treated at length below. The government project is the threatening backdrop against which they work, and centers on plantation agribusiness and plantation forestry. Both have important political implications: whereas the government vision reflects modernizing and globalizing agendas, the environmental agenda seeks a more local, self-determined political future. 
In Chimalapas, the most influential and visible NGO is MPS, which has proposed and is working to plan and implement a campesino ecological reserve. Although its founders and directorsare urban M exicans, about half of the 60 paid staff members of MPS are campesinos from the communities of Chimalapas. According to Maderas, if implemented the locally controlled reserve would solve a border dispute between $\mathrm{O}$ axaca and Chiapas, as well as agrarian ambiguities which make it impossible to regulate and control land use practices in the area. At the same time, as a Campesino Ecological Reserve and not a Biosphere Reserve or National Park, the Chimalapas forest would remain under local control. Thus, the campesino reserve would unite about 40 often fractious communities into one piece of protected property, which in its ideal form would be both ecological and autonomous (Anaya and Álvarez, 1994) .

As a forest region and a collectivity of agricultural communities, Chimalapas has had, and still faces, a complicated morass of unresolved agrarian problems. Its communities are poor, roadless, unlit, lacking the most basic services, such as wells for water and bodegas for food. Government agents rarely arrive at the outlying areas, dreading the long walk, fearing ambush and in any case having few resources to offer once they get there. $\mathrm{O}$ ften deforested, these communities have been claimed by invading cattle ranchers, beset by forest fires and disrupted by a toxic combination of narcotraffickers and soldiers. Remote, yet not far off the PanAmerican $\mathrm{H}$ ighway, groups of illegal immigrants from as far away as $\mathrm{Nicaragua}$ and $\mathrm{EI}$ Salvador make their way on foot through this ter rain on their long journey to the United States, sometimes dying of hunger and fatigue. Partly in response to the significant presence of NGOs and their money in the region, State and federal government agencies are extending themselves to offer and confer infrastructural as well as ecological development projects in the zone. However, these projects are largely confined to the two municipios, Santa María Chimalapa and San Miguel Chimalapa, whose political decisions determine the ability of NGOs in the region to carry out their work.

Within Chimalapas, the poorest, most peripheral communities have all lied themsel ves with the NGO, MPS. In contrast, the leadership of the two controlling municipalities reject the Campesino Reserve and its supporters. Instead, they receive government support and services. Thus, a picture emerges of an extremely marginalized MPS constituency. They control no forestry permits (which belong to Santa María and San Miguel), and live in a forest not able to sustain the usual agricultural practices. And so they turn to civil society alternatives and their visions of autonomy and ecology. Mean while, those communities which have most to gain by supporting the PRI, in terms of jobs on infrastructural projects, tend to do so.

But Maderas del Pueblo does not claim to have 'political' ambitions. Members of the organization often referred to something they called sociedad civil, civil society, which was conceived as the opposite of gobierno, 
or government. They reject all political parties and political affiliations, and do not aspire to become a political force (in the sense of a party like the Greens). According to Miguel Angel Garcia, the Director of Maderas del Pueblo:

... there is a line: on one side is the government and on the other side civil society. There is going to be negotiation, [ but] no playing the little game where we mingle, which is where co-optation starts. ( L a L ucha por Chimalapas, 1993: 104; cited in U mlas, 1998: 170)

Yet, between Mexico's federal environmental agency, SEMERNAP, universities like Chapingo and UNAM which had ecological curricula, and the NGO sector there was a lot of cooperation and exchange. Some individuals working in SEMERNAP had previously been members of the Pact of Ecological Groups, a coalition of environmental groups which support the CNDC. Future activists and officials, many of whom were biology students at the universities, met and mingled and made friends. These friendships and sympathies were important for negotiating policy. As the gulf between the governmental and non-governmental sector in Chimalapas grew, so did enmity among formerly friendly individuals. Activists derisively refer red to individuals who worked for government agencies as bureaucrats, people lacking in autonomy and self-serving turn-coats.

Likewise, some campesino members of MPS had previously been allied with PRI-sponsored campesino organizations. Municipal authorities of San Miguel had broken with MPS only to later return. In 1995 the sympathetic local government of Santa María Chimalapas was replaced by a set of authorities who were hostile to the MPS project. MPS was subsequently expelled from the community, its members threatened with hanging if they returned. A few months after the Foro described below, the sympathetic government of San Miguel was replaced by a hostile one (according to election observers, campesinos were paid 200 pesos and a machete to vote for the candidates with PRI sympathies).

During the period of my fieldwork, 1996-7, the relationship between MPS and government agencies at both the state and federal levels had become so strained that 'mingling' was out of the question. Even negotiation seemed far out of reach. One government official I talked to referred sarcastically to MPS as 'saints', another derided them in mock imitation, saying, 'Oh, the poor people, the poor forest, the poor animals. Poor Chimalapas.' In more formal interview settings, government officials almost always told me the watermelon joke: why is an ecologist like a watermelon? Because it is green on the outside and red on the inside.

One INE (National Institute of Ecology) official implied that MPS was refusing to negotiate with the government in order to forestall a solution to the problem, implying that the implementation of a campesino reserve would also signify the end of MPS's usefulness and of their internationally funded salaries. Another government official accused the group of 
interfering with the democratic opening in Mexico, because its members were too 'red', thus suggesting guerilla ties or tactics. In this way, the group was discredited as 'fringe', while the democratic opening was attributed to the state. Yet, of the informants above, at least three had been closely allied with MPS or its network of left-leaning environmental groups in the past. While these officials accused MPS of profiting from the problems of Chimalapas, M PS workers suggested that these former allies in government posts had abandoned their ideals for a salary.

NGO and government projects alike were dependent on community legitimization and were active in imagining, creating and representing this community. To return to the invitation ( which was written by MPS):

The Chimalapas forest is currently the most biodiverse region in Mexico and perhaps in Central America, keeping a high degree of conservation thanks to the ongoing struggle of its indigenous communities, inhabitants and ancestral caretakers of the aforementioned territory. In the last few years, the aforementioned communities of Chimalapas have stepped up their struggle in the defense of their territories and wilderness in the face of a concerted attack on the part of cattle ranchers, loggers and drug traffickers. As a result, they have realized the necessity of protecting their forest, taking the initiative to construct, by their own decision, an Ecological Reserve, the administration and management of which would remain in their hands. To this new model they have given the name CAMPESINO ECOLOGICAL RESERVE. Now, the Chimalapan communities, in order to hear opinions, doubts, understandings and proposals of civil society (campesino organizations, ecologists, conservationists, academics, investigators, lawyers) about the Chimalapas Forest and its Reserve, are meeting and inviting participation in the Forum of Community and Civil Society on the Chimalapas Forest. (My translation)

In the invitation Chimalapas is identified as the most 'ecologically diverse' region in Mexico. The problem in Chimalapas is represented as a twofold ecological problem: on the one hand, positive ecological depredations endanger the forest. These are side effects of extractive capitalist activities such as ranching, logging and drug trafficking. On the other hand, something or someone is preventing the communities of Chimalapas from protecting their own environment. The solution to the problem is to constitute Chimalapas as an autonomous unit, which would administer itself as an ecological reserve.

The land/ environment is the common denominator which unites the inhabitants of Chimalapas ( who live in about 40 communities, few of which are linked by any direct road or path) as one community. Identity rests not in any named ethnicity (there are about 15 different indigenous groups and languages represented among Chimalapas' 15,000 inhabitants), but in belonging to one of the communities of Chimalapas. These community members are either indigenous inhabitants, non-indigenous in habitants, or those who are ancestral caretakers. All have conserved the land through an unspecified struggle and are aware that it will be threatened if they do not take action as a community. 
This community speaks with an independent voice, gaining its authority from its assertion that as it has al ways cared for its lands, it should continue to do so as an autonomous ecological reserve. Importantly, what is invoked here is not the community authority ( which is a political post) but community authority. As such, it speaks to an organized community of people, the larger civil society community, but not its authorities. Thus, the two communities - those who are indigenous and non-indigenous inhabitants and caretakers, and those who are members of a civil society community - are linked in a common moral community.

In the semiology of Chimalapas (told by Maderas), politics are tainted and community is pure. Political leaders from the municipalities, whether allied with the NGO or not, were described by urban NGO staff as shifty, untrustworthy, uncivilized, rude and sexist. All political parties were corrupt or co-optable. Electoral politics were a sham. While the municipalities were tainted by politics and power, the smaller settlements in the forest had an edenic aura. The 'people' referred to the inhabitants of the forest settlements outside of the immediate control of the powerful (and tainted) municipality. The forest setting, its beauty, remoteness, isolation and powerlessness, cleansed the recent settlers of their past politicized/powerful campesino status. Representations of these communities usually included women, children, old people and animals: an association made between vulnerable places and innocent creatures. Civil society occupies a brokers position in this scheme: self-consciously post-political, it links itself to local political actors as well as a professionalized class of NGO workers, and dreams of a future autonomy founded on unspecified 'traditional' community modes of organization.

I would like to juxtapose this invitation, which asks us to lend a particular interpretation to the events, with the document that follows. On 10 O ctober 1996, two days before the commencement of the Foro, a desplegado (accusation) appeared in La Jornada, a nationally distributed newspaper. It was addressed to President Zedillo, Emiliano Chuayffet, the Secretary of State, Jose Angel Gurria, the Secretar y of Exterior Relations, Julia Carabias, the director of the federal environmental agency (SEMERNAP), and Diodoro Carrasco, the governor of Oaxaca. It reads:

The undersigned, municipal authorities of Santa María and San Miguel Chimalapas, and the agrarian representatives of Santa María Chimalapa publicly denounce the 'N ational Committee for the Defense of Chimalapas', 'The Pact of ecological Groups', and 'Maderas del Pueblo del Sureste', A.C., for usurping the representation of the Chima people, with the end of obtaining economic resources from international organizations.

These pseudo ecologists (who capitalize on the struggle of our people only by signing protests, and thus their halo comes at our expense), directed by Luis Bustamente and Miguel Angel García, ${ }^{7}$ have been receiving 7 million pesos [about a million dollars in 1996] annually from the British Embassy, ${ }^{8}$ The World Wide Fund for Nature (WWF) and the Rockefeller Foundation, that supposedly are applied in works of ecological protection and development of 
our communities. However, we haven't seen any concrete result, nor received any explanation about the management of those resources. For this reason in the General Assembly which took place on the 14th of January, 1996 in the municipality of San Miguel Chimalapa, it was unanimously decided to expel these organizations from Chima territory, a decision reiterated in the General Assembly of September 22 of the same year. In the same way, on the 14th of May of 1996 the General Assembly of Comuneros of Santa María Chimalapa roundly rejected the divisionist politics that the ecologists carry out in the congregations, censured the management of the resources obtained in the name of the Chimas and forced them to declare their leaving in light of the fact that they had not justified with work and deeds the application of the huge sums of money that they obtained using our name and the pretext of safeguarding our natural resources. It is for this that we ask the intervention of the Federal Government so that international support to these groups is canceled and redirected along reliable lines in a show of respect to the local authorities. These people will stop at nothing to continue receiving the money of international organizations, therefore we hold them responsible for our personal security, for the security of our families and of our lands (bien es). We want to live in peace! We want to speak for ourselves, therefore we will not accept that Luis Bustamente, nor M iguel Angel García, nor anybody speak for the Chima people. For all of the above, we deauthorize the supposed 'Communal Forum of Civil Society on the Chimalapas Forest' that they are trying to carry out the next 12th of October in our territory with the idea to disseminate the image that they represent the Chima people, and we ask ecological organizations which act in good faith to not be fooled by these supposed social redeemers. (La Jornada, 10 October 1996, my translation)

In this accusation NGO s are accused of misrepresenting themselves as members of the community and of appropriating the representation of the Chimas. They are the predators, the Chima their prey. These 'pseudo ecologists' destroy community by promoting political divisions: they fragment the community.

These voracious outsiders are juxtaposed to a helpless 'Chima' who now must ask for federal intercession on his behalf. This emotional rhetorical appeal is offset by the linkage of community will to local authority. In this text, community will rests within the pronouncements of its legitimate ruling bodies. Thus, the protest argues that international foundations should give their monies directly to the authorities of the two municipalities of Chimalapas. Likewise, the protest is directed toward the highest authorities in the country and the state. While in the invitation, authority rests in civil society, in the protest, authority rests in elected leaders. Interestingly, the accusation does not apply to all ecologists (just pseudos), implying that not all civil society groups are included in this rejection. Care istaken not to reject the democratic opening itself and thereby position the government outside of it. I will return to the accusations launched against the ecologists and their response to the accusation in the conclusion. First, I would like to discuss the representations of civil society and community at the Forum itself. 


\section{Civil society and community at the Foro}

The invitation, as noted above, immediately conjures up images of the Zapatistas, who have held several 'national forums' in the Lacandon Jungle. Their forums have attracted thousands of activists and NGO representatives, who are housed in makeshift barracks. The Forum in Chimalapas was similarly held in a remote and forested area, rather than in the municipio of San Miguel, which has a graded dirt road, and is close to the Juchitán (the largest town in the area) from where it is possible to get a microbus or truck transports to San Miguel Chimalapa. Instead, attendees met in Zanatepec, a small cattle ranching community, and were transported to Benito Juárez in trucks and buses. The road to Benito Juárez winds up to the top of a precipitous hill, after several hours finally opening out into a clearing in the forest, where Benito Juárez is nestled. Activists involved in advocacy for Chimalapas, many of whom are urban M exicans and have never traveled to Chimalapas itself, thus experienced Chimalapas in its most pristine 'remoteness'. Significantly, MPS was absent as an overt force or 'voice' at the Forum which they had organized. Only campesino members of MPS spoke, and then wearing their 'community member' hats.

The program began with breakfast on Saturday morning. This immediately lent an air of domesticity and comfort to the conference. Women from the community worked in makeshift kitchens, serving beans, tortillas, coffee and animal crackers on plastic plates and utensils, all provided by MPS. Women from San Antonio Nuevo Paraíso set out their Chimalapas t-shirts for display and sale.

The conference opened with welcomes for the several hundred attendees and was followed by a series of speeches by political leaders from Chimalapas, who recounted important episodes in Chimalapas' agrarian struggle. In this history of Chimalapas, speakers related its past and present struggles in such a way as to unite agrarian struggles of the past with the current NGO project. The telling of community history emphasized ancestral rights (crucial to the legitimization of land tenure claims in relation to agrarian agencies) yet accommodated the fluid ethnic composition of Chimalapas. Many of its communities are newly settled by various indigenous groups. Thus, the Zoque who were once the majority in the area, and who peopled Santa María Chimalapas during colonial times, are now outnumbered by immigrants. These multi-ethnic immigrants, along with the Zoque, are reclassified as 'Chimas', their identity and culture both (re) historicized and territorially ( $\mathrm{re}$ ) defined.

In contrast to this affirmation of community strength, linked both to ancient municipal rights and the rejuvenating influence of immigration, in the testimonials which followed speakers recounted their experiences of the often illegal development process which has repeatedly threatened their own livelihoods and individual safety. For example, Doña Angela, the only female speaker and the most moving, described the murder of her 
husband and her eldest son, who had settled on previously 'vacant' communal lands belonging to Santa María Chimalapas. These forested lands, located far from the municipality itself, had been used for years as pasture by cattle ranchers from neighboring Chiapas. When Doña Angela's family moved in with the permission of the authorities of Santa María Chimalapas to establish a new community, they were murdered by the cattle ranchers. In her testimony, Chimalapas is feminized: its victimized status underlined at the same time that the feminine role is played out. It is important to note that women, generally excluded from local decision making, were brought to protests and meetings, not only to cook and care for children, but also to symbolically underline the powerless position of the Chimas in relation to the state.

During the remainder of the conference, discussions and presentations linked community identity to the environmentalist project. This was to prepare for a protest and march the following week in the city of Oaxaca, where there was a public representation of the environmental community. First, comun eros from San Francisco La Paz presented campesin o maps detailing a land use plan for their area, which they completed under the MPS Campesino Ecological Reserve project. This map showed how the community would farm and graze in an ecologically sustainable manner. Then SERBO , A.C., an NGO which has in the past few years carried out a detailed study of present ecological conditions in Chimalapas, presented a slide show of the (at the time, unpublished) results of their recently completed evaluation:

[These slides of Chimalapas were made] with photographs that were taken by some objects which circle the Earth and that are called satellites, that are like cameras which take images of the Earth below. These images are a little different than the photographs we take here of the countryside, the colors above all. I want to give a big thank you to the communities that above all here in O axaca gave us permission to visit their forest lands, accompanied us, hel ped us, put us up and showed us great hospitality. I believe that almost all of the communities of Chimalapas are represented here and I want to thank them for making it possible for us to carry out our study. Also, I would like to thank the organizations and foundations that supported us and collaborated in thisstudy.

In this segment of the presentation, the speaker emphasizes the dependence of NGO supon community hospitality - the sign of their legitimation of NGO projects in the region. $\mathrm{He}$ also acknowledges a debt to international funders and foundations, thus linking the SERBO study to a global environmental project. He then goes on to outline the SERBO assessment of the ecological condition of the Chimalapas forest:

$\mathrm{H}$ ere in this other map we have 30 different little colors, no? And this gives one a bit of a headache but it can be simplified and we can make a pretty simple classification that would give one color, green, to all of the wilderness which is conserved. The zones or areas which show fragmentation, where the natural vegetation and the animals and plants are on the defensive, are yellow. Totally 
deforested areas are red. We see that the area in the municipal limits of Santa María and San Miguel Chimalapas contain conserved forest that are green. Zones where the forest is al ready losing the battle are at the entrance to Santa María Chimalapas, Cuauhtemoc where the forest has already lost the battle, and where right now the battle is happening - the forest is being fragmented in the northeast zone.

$H$ is use and simplifying explanations of satellite images highlights the divide between campesino and urban technologies. Likewise, the SERBO discussion of ecology, which uses technical terms to describe vegetation, and emphasizes endangered flora and fauna, differs from campesino presentations, which, as we will see below, place more emphasis on poverty and lack of control over natural resources. Also important here is the fact that the areas within the limits of Chimalapas are green, and therefore ecologically healthy. Deforestation problems are encroaching upon its entrance and in surrounding areas. This fact is significant, as the speaker goes on to explain:

This is a phenomenon that worries us ecologists quite a bit. We have a great forest here, a good forest there that is a reserve already and that is connected still. O ne could say that a jaguar can still look for his girlfriend in another jaguar here or a jaguar over there and he doesn't have to be resigned with only those that are in his own area. These are bridges of natural vegetation which the animals need. For example, the tapir and the jaguar and many birds and other animals and also plants need to intermix and communicate with others to keep themselves healthy. But these bridges are being destroyed .

Particularly interesting is the use of the jaguar's plight to describe the dangers of ecological fragmentation. If the jaguar can't move from one area of the jungle to another, he will be limited in his choice of mates. In evolutionary terms, genetic diversity will be restricted, and the species will die out. Translated into human terms (the jaguar will not be able to pick and choose among girlfriends), the image is at once sexual, humorous and accessible. It also serves as a poignant metaphor for the civil society project itself, which seeks to unite the fragmented communities of Chimalapas against powerful global processes of political and economic development. These global forces are referred to in the next segment of the slide show:

Right now we will turn more to numbers to see what this means in hectares. We are able to say that these two areas that comprise the communal lands of Santa María and San Miguel Chimalapas still have around 80 percent of well conserved wilderness, 16 percent is fragmented and 5 percent is already deforested but this is a very small part and if we compare it to the North toward Veracruz here we would have almost one hundred percent of red deforested, a little tiny bit of fragmented and almost nothing conserved. The comuneros have shown us that here the forest is still conserved. To conserve it in the future will require a lot of effort and of ever yone.

$\mathrm{H}$ ere the speaker emphasizes that Chimalapas is still a viable forest, and he attributes this to the inhabitants of Chimalapas. The deforested areas he 
refers to in Veracruz are part of the same forest system that were deforested during modernization programs of the 1970s which promoted colonization, industrial timber production and infrastructural development projects such as dams (Toledo, 1995). The speaker goes on to enumerate more specifically the contemporary causes of deforestation:

If we see the ecosystems or let's say not so much ecosystems, but the soil uses of these zones that are deforested, that represent for Chimalapas 5 percent or 30 thousand hectares, we will see what causes deforestation. And we see, obviously, that it is the pasturing, ranching and secondary vegetation that is also linked to the pastures that causes the great majority of the deforestation. Seasonal agriculture, here, represented as AT, Agricultura temporal, is less than 0.9 percent; what it means is the AT hasn't been the cause of deforestation, that is, the campesinos who grow corn and beans and all this, are not deforesting important areas of Chimalapas. Rather it is the pasturing, the cattle ranchers, the ranching which is causing the great part of the deforestation. (Marco, SERBO, A.C. 12 O ctober 1996, my translation)

Like community speakers, Marco attributes the environmental problem to predatory outsiders - cattle ranchers and loggers ( often illegal agents of timber companies). $\mathrm{H}$ is analysis extends beyond the campesino critique to conclude that agricultura temporal (that is, seasonal agriculture or 'slash and burn') is not the major cause of deforestation in the zone. This taps into a large academic debate carried out between political ecologistswho blame environmental degradation on capitalist expansion into wilderness zones - and mainstream theorists, who attribute environmental problems to population growth and primitive agricultural practices (such as slash and burn). ${ }^{9}$ The satellite images, which show Chimalapas to be more preserved than the areas outside its borders, and the evidence about the causes of ecological degradation, contribute to the legitimization of the Chimalapan demand for a locally controlled ecological reserve.

The next day, the program commenced with M esas de trabajo (work groups) - where participants split into discussion groups. The topics were: the agrarian problem, the Campesin o Ecological Reserve, autonomy, use and management of resources, and infrastructure and social problems. Each work group was led by a campesin o leader, who presented the results of the discussion when the group reconvened as a whole.

I sat in on the Ecological Reserve discussion, which mostly involved a lot of discussion about agrarian problems that campesinos were experiencing. The results were presented by the group leader as follows:

What are we going to do so that the Campesino Ecological Reserve functions? The land must be conserved. We ask that the government give the reserve legal recognition. We need to combat poverty. Poverty is serious for those who are disabled or blind. In Chimalapas we are rich but we don't know how to make use of the land. The opinion of the campesinos that met at table 2 is that we must organize the people and well, there were different opinions, but we all had the same goals. 
Enrique's summar y accurately reflects the type of discussion that occurred in work group 2. Charged with discussing implementation of a Campesino Reserve, participants quickly moved on to other issues. O ne recurring theme was the problem of poverty and the powerlessness of community members living in a 'rich' zone to combat it. This powerlessness over local resources is attributed to the imperialistic intervention of government and outside projects. One such project is a government-favored biosphere reserve. It was presumed that a federally mandated reserve would privilege ecological goals over the social ones promised by a local campesino ecological reserve:

Let's go to the next question: Who is going to do it? The government wants to impose a biosphere reserve but doesn't consult with the campesinos. Thus, it is the opinion of the campesin os that we want the community to do it, we ourselves the campesin os. We can care for the forests because they are ours. That is, since we live here we know how to tend it and the truth is that all that is missing is recognition to be able to go ahead. No government is going to protect it because only to us is it important. We mustn't allow others from the government or from other countries to come to look after us... we must be organized. These are the opinions of the campesin os that were here....

$\mathrm{H}$ ere the speaker suggests that a biosphere reserve designation for Chimalapas would constitute an intervention and would disempower campesinos.

We still need to address the following question: How are we going to do it? It is: The rational use of the timber, making a rule about natural resources in each community to make an internal regulation, organizing all of the comuneros from different communities of Chimalapas to prevent logging, and to impede the extension of [ logging] permits to people from the outside. The government is cor rupt and because of this we must say our piece. (Eduardo, 13 October 1996, my translation)

In this presentation of the results of the campesino reserve discussion, the ecological campesino reserve is mentioned only once. NGOs and international funders are not mentioned at all. Instead, the presentation begins with a discussion of poverty, and of poverty in the face of a wealth of natural resources. While the ecological problem is not described, the community role in caring for the forest is emphasized repeatedly. The problem is presented as a specifically local one, where outsiders enter the communities with logging permits, granted by SEM ERNAP, the federal agency that regulates forestry. Thus, rather than seeing the ecological problem as part of a global fight against deforestation and biodiversity loss, the communities see it as a local problem stemming from the refusal of the federal and state government to grant local control of resources to forest communities.

Both M arco and Eduardo legitimize the autonomy project through their respective representations of the environmental problem. While it is not clear how the more ' $g$ lobal' NGO conservation vision is linked to the local autonomy project (community members don't speak specifically about how they envision conservation or understand the SERBO project), both 
treatments trace the roots of the problem to the same cause (capitalist development of resources). NGOs, legitimated by the community through the concurrence of two projects ( saving the ecology for the NGO s and safeguarding the community territory), would also legitimate themselves within a post-socialist political climate through their alliance with international environmental groups and an international concern about ecology.

After the conference described above, Maderas and participating community members took their message on the road, in a march of Viejos y Niños (Old People and Children), to demand agrarian solutions and implementation of the Campesino Reserve. They also sponsored a rock concert with Cielo y Tierra and Guillermo Briseño of the popular rock band Mana to publicize Chimalapas and its problems. Participants camped out in the central plaza. Their colorful banner showed sweet but fearful campesin o faces poking from the forest leaves, huddled defensively together with a pair of jaguars.

\section{Summary and conclusions}

As must now be evident, this civil society project is eminently political, tapping into the worst fears within the government about loss of control and ethnic fragmentation. Thus, government opposition to the project is strong. The denunciation which appeared in the nationally distributed newspaper, La Jornada, during the week of the Foro demonstrates the precariousness of NGO legitimacy. In it, The CNDC and M PS were accused of being psuedo-ecologists who had appropriated the representation of Chimalapas in order to get funding from the WWF. The denunciation accused MPS of promoting political divisions among the communities of Chimalapas. Finally, it announced the fact that MPS had been officially expelled from Santa María Chimalapas, the largest and most powerful municipality, in May, a few months before the Foro took place. Although publicly the Foro was proclaimed a success, in private it was acknowledged that attendance was much lower than expected. Members of MPS opined that this denunciation had scared villagers off. Another factor which probably contributed to attrition at the Foro was the sudden militar y presence in the area at the time of the conference. There is periodic militarization in Chimalapas, purportedly as a check against drug traffic. However, this check clearly coincided with the Foro and was a deterrent to prospective attendees. This was unfortunate for the MPS, since in part the Foro was intended as a public demonstration of the strength of the Campesino Reserve, and of its popularity within the communities of Chimalapas.

During this period, and in spite of the representation of community solidarity at the Foro, the WWF decided not to renew their grant to Maderas del Pueblo. The mission of the WWF in developing countries is to fund conservation projects which can be supported at the grassroots level, and instituted by developing countries at the federal level. The WWF stopped 
funding MPS because of its inability to negotiate its campesin o reserve plan with the government. According to the Oaxaca director of the WWF:

The strategy of MPS and the CNDC, it seems to me, is the principal point of difference between the WWF and Maderas del Pueblo. We see the problem in the same way, but have different strategies to confront it . . . we don't want to carry out an agenda that is 100 percent political since there is little political will or space for negotiation with some interest in solving the problem and not to make political capital out of the problem. (Javier Castañeda, personal communication, 15 May 1997) 10

In other words, Maderas del Pueblo was so busy making its larger political points - against NAFTA, large landholders, the cattle ranching way of life, poverty and inequality - that it did nothing but draw fire from the government. What had happened in the past few years that MPS could no longer negotiate its Plan with the federal government? How had MPS, which has great credibility as an effective local actor, come to be expelled from one of Chimalapas' largest municipalities and cut off by a major funder?

This is too large a question to answer in this space. However, one of the reasons for the declining legitimacy of the NGO in the main municipalities was the successful appropriation of civil society discourse and networking practices by the local government. Among the major complaints of the NGO is that the state government had established an office near Chimalapas in order to interfere politically in the community. This Delegation, located in Matías Romero, was staffed by and reports directly to Diadoro Carrasco, the Governor of O axaca. It was assumed, by both MPS workers and some federal government officials with whom I spoke, that the accusation in La Jornada had been planted by the Delegation.

This office also coordinates a committee pertaining to Chimalapas, made up of the heads of communities as well as government development, environmental and agrarian agencies. MPS does not have a representative on this body, but MPS workers claim it was their idea to create such an entity in order to cut through the complex web of interlocking agencies whose contradictory policies make problem-solving in Chimalapas so difficult. This coordinating entity was coopted by the government in order to reduce the power of MPS. MPS responded by backing out of negotiations concerning the establishment of a Campesino Reserve. Government officials insist that campesinos from the communities feel victimized by MPS, and accuse MPS of interfering in local politics. According to the Delegation, campesinos have invited the state government to take a more active role in solving problems in the area (Sergio Guerrero, personal communication, $23 \mathrm{March}$ 1997). ${ }^{11}$ Indeed, the Delegation was actively promoting its own silvicultural and agricultural projects in Chimalapas. The municipal authorities of Santa María Chimalapas were more often to be found in the Delegation office than in their own village.

While Federal officials and WWF officials with whom I spoke referred to the Delegation and its activities with repugnance, by the end of my stay 
both the WWF and SEMERNAP were actively cooperating with this agency and with the State Institute of Ecology (IEE), an agency more noted for its closeness to the Governor than for its ecological expertise. Both these agencies were represented at a conference cosponsered by WWF, SEM ARN AP and SERBO, A.C. in June of 1997. Campesino members of MPS attended, though wearing their community hats. They insisted that neither they nor MPS had been officially invited. The director of the Oaxaca office of WWF denied that this was true. Whatever the case may be, this conference certainly indicated the distance which had grown between MPS and its former allies, as well as the success of the state government in gaining a foothold in Chimalapas.

The WWF distanced itself from MPS because its major priority was to codify environmentally sustainable practices into local customary law. In 1995, they provided financial support to Maderas to work toward this goal. Maderas drafted a community statute which referred to a campesino ecological reserve. On the eve of its passage by the community assembly in Santa María, a new set of pro-PRI authorities took office. They struck down the statute and expelled Maderas del Pueblo. By 1997, the WWF was funneling its funds into state level environmental agencies working in the area, who were now the only ones in a position to build community support for a codified ecological reserve.

The irony in the relationship between civil society, its funders and the government must now be very clear. US-Aid insisted that democracy in Chimalapas could only be advanced through 'organization and communication' between the 'stakeholders' of Chimalapas: such as campesinos, cattle ranchers, loggers, and government agencies. Ideally, an NGO like MPS would act as some kind of neutral arbiter among these interests. Yet ultimately, this civil society solution did not prove satisfactory to its funder. On the one hand, the visions and goals of MPS did not center exclusively on immediate technical solutions to the environmental crisis in Chimalapas. On the other hand, the only arbiter in the region which had the power to generate organization and communication among the scattered communities of Chimalapas proved to be the state government.

Further, although the entitlement of the newly ethnicized Chimas to their territor y was not challenged by either side, the right to represent them was highly contested. Likewise, where Maderas del Pueblo argued that their intervention would unite these fragmented communities into a unified power-bloc against global political and economic forces, the government clearly sought to represent the NGOs as an imperialist threat.

Thus, under the aegis of democratization, a project intended to amplify the community voice through 'civil society' was transformed into an opportunity for the state to insert itself further into the community. By the end of 1997, when I left my fieldsite, Chimalapas had no protected designation, no ecological reserve. Negotiations over the community statute were at a standstill. Tired of the truckloads of delegates and officials, NGO members 
and anthropologists at their town assemblies, they had stopped showing up for the meetings altogether.

\section{Notes}

1 Jim Rieger and Frank Zadroga, US-AID. Interview by author, Mexico D.F., 17 January 1997.

2 Through the Pact of Ecological Groups (PGE) and the Committee for the Defense of Chimalapas (CNDC)

3 Secretaría de Medio Ambiente, Recursos Naturales y Pesca (SEM ARNAP: Secretariat of Environment, Natural Resources and Fishing); Instituto $\mathrm{N}$ acional de Ecología (INE: National Institute of Ecology) and Instituto Estatal de Ecología (IEE: State Institute of Ecology, O axaca State).

4 Secretaría de Reforma Agraria (SRA: Secretariat of Agrarian Reform) and Procuradería Agraria (PA: Agrarian Agency).

5 George Collier (1994) discusses the long-term involvement of left political activists in the Lacandon Forest.

6 Marijuana and opium poppies are known to be grown in the area, but activists and locals attribute the most serious drug trafficking activities to outsiders who use Chimalapas as a node in an overground transport route between Colombia and the U nited States.

7 Both are Directors of the National Committee for the Defense of Chimalapas, an alliance of NGOs and individuals who support MPS in their efforts.This alliance was formed in 1991, in order to stop the construction of a proposed highway through Chimalapas. Miguel Angel García is also the Director of Maderas del Pueblo.

8 This refers to the British O verseas Development Agency (ODA). The ODA is also a major funder of Maderas del Pueblo.

9 See, for example, Painter and Durham (1998); Place (1993); Sponsel et al. (1996) for critiques of development policy.

10 Javier Castañeda, Director of the Oaxaca office of the WWF. Interview by author. O axaca de Juárez, O axaca. 15 M ay 1997.

11 Sergio Guer rero, O axaca State Delegate for Chimalapas. Interview by author, 23 March 1997.

\section{References}

Anaya, Ana Luisa and Marcela Álvarez (1994) Plan de Desarollo y Conservación de una Reserva Campesina en Los Chimalapas. México, D.F.: Instituto Nacional de Ecología.

Chalmers, Douglas, Judy Gearhart, Andrea H etling, Adam Jagel ski, Kerianne Piester and Caroline Tsilikounas (1995) 'M exican NGO N etworks and Popular Participation'. Papers on Latin America 39. Institute of Latin American and Iberian Studies, Columbia University.

Cohen, Jean L. and Andrew Arato (1994) Civil Society and Political Theory. Cambridge, MA: MIT Press.

Collier, George (1994) Basta! Land and the Zapatista Rebellion in Chiapas. O akland, CA: Institute for Food and Development Policy. 
Collier, George and Lynn Stephens, eds ( 1997) 'Ethnicity, Identity and Citizenship in the Wake of the Zapatista Rebellion', Special Edition, Journal of Latin A merican Anthropology 3(1).

Consejo Asesor Técnico y Científico para el Manejo y Protección de Los Chimalapas (1997) H acia una Zonificación de Áreas Prioritarias para la Conservación de los Recursos $N$ atu rales y la Biodiversidád de L os Chimalapas, O axaca. O axaca de Juárez, O axaca, 27-8 June.

Dagnino, Evelina (1998) 'Culture, Citizenship and Democracy: Changing Discourses and Practices of the Latin American Left', in Sonia E. Awarez, Evelina Dagnino and Arturo Escobar (eds), Cultures of Politics, Politics of Cultures: Re Visioning Latin American Social M ovements.

Daven port, Russell (1995) 'M exico Ecodevelopment Program: Midterm Evaluation Final Report'. Unpublished MS, prepared for the Biodiversity Support Program.

Dirks, Nicholas B., Geof Ely and Sherr y B. Ortner, eds (1994) Culture/ Power/ H istory. Princeton, NJ: Princeton University Press.

Fox, Jonathan (1994) 'Latin America's Emerging Local Politics', Journal of Democracy $5(2): 105-16$.

Fox, Jonathan (1995) 'Governance and Rural Development in Mexico: State Intervention and Public Accountability', Journal of Development Studies 32(1) : 1-30.

H amnett, Brian (1999) A ConciseH istor y of M exico. Cambridge: Cambridge University Press.

Harvey, Neil (1998) The Chiapas Rebellion: The Struggle for Land and Democracy. Durham and London: Duke University Press.

Hellman, Judith Adler (1992) 'The Study of New Social Movements in Latin America and the Question of Autonomy', in Arturo Escobar and Sonia E. Alvarez (eds) The Making of Social Movements in Latin America. Boulder, CO: Westview Press.

Hellman, Judith Adler (1994) 'Mexican Popular Movements, Clientalism and the Process of Democratization', Latin American Perspectives 21(2): 124-42.

La Jornada (1996) 'Desplegado'. 10 O ctober.

Maderas del Pueblo (1996) 'Hacia Una Reserva Ecológica Campesina en Los Chimalapas: Programa de acciones 1995-1996, segunda versión'. U npublished MS.

Maderas del Pueblo (1996) 'Foro Comunal y de la Sociedad Civil sobre la Selva de Los Chimalapas', Benito Juárez, Chimalapas, 11-13 0 ctober.

Nash, June (1998) 'The Militarization of Civil Society in Chiapas', un published MS.

Painter, Michael and Willian H. Durham, eds (1998[1995]) The Social Causes of Environmental Destruction in Latin America. Ann Arbor: University of Michigan Press.

Place, Susan E., ed. (1993) Tropical Rainforests: Latin American Nature and Society in Transition. Jaguar Books on Latin America Number 2. Wilmington, DE: Scholarly Resources.

Sponsel, Leslie E., Thomas N. Headland and Robert C. Bailey, eds (1996) Tropical Deforestation: The H uman Dimension. New York: Columbia U niversity Press.

Toledo, Alejandro (1995) Geopolítica y Desarrollo en el Istmo de Tehuantepec. Mexico D.F.: Centro de Ecología y Desarrollo.

Umlas, Elizabeth (1998) 'Environmental Networking in Mexico: The Comité Nacional para la Defensa de los Chimalapas', Latin American Research Review 33(3): 161-87. 
Critique of Anthropology 21(4)

- Molly Doane has a PhD (2001) in Anthropology from the Graduate Center of the City University of New York. She is currently Visiting Professor at the University of O klahoma. Address: Department of Anthropology, Room 521, 455 West Lindsey, Norman, OK 73019, USA. [email: madoane@ou.edu] 